\title{
HYBRID ORGANIZATIONS
}

Thomaz Wood Jr.

Professor, São Paulo Business School, Fundação Getulio Vargas - São Paulo - SP, Brazil
One major attraction for visitors of the Brazilian Amazon rainforest is the "meeting of waters," a phenomenon that occurs at the confluence between the Negro River, with its black (dark) water, and the Solimões River, with its sandy-colored water. The waters of the two rivers run side by side without mixing for more than 6 kilometers. This phenomenon is due to the differences in water density, temperature and speed of the two rivers. The Negro River flows at approximately $2 \mathrm{~km}$ per hour at a temperature of $22^{\circ} \mathrm{C}$, while the Solimões River flows between 4 to 6 $\mathrm{km}$ per hour at a temperature of $28^{\circ} \mathrm{C}$ (PREFEITURA DE MANAUS, 2007).

In this Pensata, it will be argued that a similar phenomenon is taking place in the corporate world. Since the 1990s, the increasing speed of organizational change processes (KANTER, STEIN \& JICK, 1992; WILSON, 1992), the growth of merger and acquisition processes (GREGORIOU $\&$ RENNEBOOG, 2007; MARKS \& MIRVIS, 1998; THE ECONOMIST, 1999a; THE ECONOMIST, 1999b; VASCONCELOS, CALDAS \& WOOD, 2003) and privatization processes, particularly in emerging countries (RAMAMURTI, 2000), gave rise to what may be called hybrid organizations, a new "ideal type" (see LAMMERS, 1988). In Brazil, several recent cases may have generated hybrid organizations, such as the acquisition of ABN-Real by Santander, the merger between Itaú and Unibanco, the creation of Fibria, a result of the merger between Aracruz Celulose and Votorantim Celulose e Papel, and the creation of Brazil Foo$\mathrm{ds}$, a result of the merger between Sadia e a Perdigão.

This paper seeks to present hybrid organizations as configurations that result from change processes and preserve for a long time, in the same organizational locus, certain distinct strategic, organizational and cultural features which originate from the matrices that formed the organization and may sometimes be antagonistic. We believe that, in addition to drawing attention to a relevant, yet poorly studied, phenomenon, this paper makes three other contributions: first, by enriching the concept of hybrid organizations; second, by revealing the dynamics underlying this phenomenon; and third, by identifying the opportunities and challenges that this phenomenon poses to researchers and executives.

The paper is structured as follows: in the second section (following this introduction), the concepts of hybridity and hybrid organization are presented based on existing literature, and a basis for a review and expansion of the hybrid organization concept; in the third section, the expanded concept of hybrid organization is outlined with a list of its causes, expressions and consequences; finally, in the fourth section (conclusion), a few opportunities and challenges that this concept poses to researchers and executives are presented.

\section{THEORY: A REVIEW OF CURRENT LITERATURE}

In recent decades, the terms "hybrid" and "hybridity," both originating from biology, were appropriated by the fields of sociology and cultural studies, with hybridity being associated with a quality, state or existential condition (see BHABHA, 2003; HARAWAY, 2000; BURKE, 2003; GARCIA-CANCLINI, 2003a; 2003b). The phenomenon can also be seen, for example, in music, when there is an overlapping, in a certain style, of elements from other styles, as in the case of jazz and bossa nova. In this section, we will address the appropriation of these ter$m s$ in organizational studies.

\section{Quasi-governmental organizations and hybrids involving social organizations}

In the field of New Institutional Economics, the term "hybrid organization" is used in reference to hybrids that operate between market and hierarchy (WILLIAMSON, 1985; 1991) or arrangements mixing contracts and administrative entities to ensure coordination between partners that gain from their mutual dependence, but need to control the risks of opportunism (MÉNARD, 2004, p. 347). However, this approach refers to intercompany arrangements, rather than organizations per se, which are the subject of this paper.

Outside this field, the term "hybrid 
organization" first appeared in scientific literature in the areas of public administration and non-profit organizations during the 2000s, in reference to organizations that operate at the interface between the public and the private sectors and address both governmental demands and business demands. According to this literature, examples of hybrid organizations include public universities that provide consulting services to private companies and research centers that conduct studies for pharmaceutical laboratories (e.g. LAMB \& DAVIDSON, 2004).

The term "hybrid organization" is also used to designate organizations that combine features of non-profit organizations, such as volunteering, mission orientation and focus on the creation of social value, with features of business companies, such as self-interest, market orientation and focus on the creation of economic value (see
ANHEIER \& SCHRÖER, 2008; HUDNUT, BAUER \& LORENZ, 2006; KOPPELL, 2003). U.S. companies Fannie Mae and Freddie Mac are examples of this type of hybrid organizations (THE ECONOMIST, 2008).

\section{Hybrids, hybridity and hybridization in organizational studies}

In addition to the term hybrid organization, scientific literature on organizations has used the terms "hybrid," "hybridity" and "hybridization" in different ways. The first group of references deals with management models and studies the effects of the global dissemination of certain managerial discourses and practices and the formation of hybrids in countries that receive such discourses and practices. The second group of references deals specifically with governance models and studies how certain models disseminate, are influenced by local rea- lity and form hybrids. Table 1 below summarizes the main contributions to the understanding of these phenomena in literature.

\section{Comments on existing literature}

A review of existing literature shows that the hybridization process and the hybrid condition in organizations contain a strong element of indeterminacy, as it may destabilize the existing reference points and blur the distinctions between local culture and corporate culture. In multinational companies, for example, corporate efforts to impose values and practices may be faced with defensive responses from local executives who mix such values and practices with their own values and practices, thus creating hybrids. Furthermore, different institutional and cultural scenarios (countries or regions) may generate different responses and different hybrids.

Table 1 - Studies on hybrids, hybridity and hybridization

\begin{tabular}{|c|c|c|}
\hline GENERAL TOPIC & FOCUS OF ANALYSIS & REFERENCE \\
\hline \multirow{5}{*}{$\begin{array}{l}\text { Management } \\
\text { models }\end{array}$} & $\begin{array}{l}\text { Cultural changes involved in the adoption of American and European producti- } \\
\text { vity models in Israel, with formation of hybrids: mixtures between foreign practi- } \\
\text { ces, local practices and also practices which were modified or given new mea- } \\
\text { nings based on the interaction between original practices and foreign practices. }\end{array}$ & Frankel \& Shenhav (2003) \\
\hline & $\begin{array}{l}\text { Implementation of production management practices of Swedish and Japanese } \\
\text { origin in a Volvo plant in Brazil, resulting in a hybrid system. }\end{array}$ & Wallace (2004) \\
\hline & Westernization (and hybridization) of the Japanese management system. & Pudelko \& Mendenhall (2007) \\
\hline & $\begin{array}{l}\text { Worldwide dissemination of Japanese production techniques and their hybri- } \\
\text { dization to address various economic and institutional scenarios. }\end{array}$ & Whitford \& Zeitlin (2004) \\
\hline & $\begin{array}{l}\text { How executives in Israel, Thailand and Mexico create hybrid value and mana- } \\
\text { gement practice formats based on cultural interactions and trade-offs. }\end{array}$ & $\begin{array}{l}\text { Shimoni \& Bergmann (2006); } \\
\text { Shimoni (2008) }\end{array}$ \\
\hline \multirow{3}{*}{$\begin{array}{l}\text { Governance } \\
\text { models }\end{array}$} & $\begin{array}{l}\text { A study on the diffusion of governance models and practices showing that the } \\
\text { dissemination of codes has caused both convergence and a certain degree of } \\
\text { hybridization in the countries that adopted them. }\end{array}$ & $\begin{array}{l}\text { Aguilera \& Cuervo-Cazurra } \\
(2004)\end{array}$ \\
\hline & $\begin{array}{l}\text { A study on the evolution of governance models in China suggesting that the } \\
\text { final model will not be a copy of the original system, but a hybrid containing } \\
\text { the best features of the most relevant models. }\end{array}$ & Chan, Luk \& Wang (2005) \\
\hline & $\begin{array}{l}\text { A study on the transient nature of governance models in Germany, with a trend } \\
\text { towards convergence. }\end{array}$ & Lane (2005) \\
\hline
\end{tabular}


The formation of hybrids may occur either by a (voluntary or involuntary) mixture of features from different types of organization and due to changes in the organization (HATCH, 1997). Reinforcing this point, Calás and Arias (1997) contrasted the concept of organizational transformation with hybridization. According to the authors, the discourse of organizational transformation is characteristic of the modernist outlook, for which it is possible to conduct an orderly process of change. On the other hand, the hybridization process, which is closer to the postmodernist outlook, presupposes fragmentation and juxtaposition of forms.

Although the literature on hybrids, hybridity, hybridization and hybrid organizations has generated some progress, it presents two points of concern. First, studies have emphasized the cultural dimension and, to a lesser extent, the mixing of management models. However, it lacks a deeper understanding of how the hybridization process occurs in organizations and how systems, processes and structures participate in and are influenced by such process. Second, studies that deal with hybrid organizations perceive them as specific contractual models (as in the case of New Institutional Economics) or as combinations between business organizations, public organizations and non-profit organizations. Thus, they fail to apply the concept to a wide range of organizations which also have a hybrid nature and do not fall into these categories. Studies on hybrid organizations could address several other issues. For example: What gives rise to a hybrid organization? How hybridity is expressed? What are the implications for management practice? What is, after all, a hybrid organization? This paper will address these issues in the following section.

\section{DISCUSSION: DIRECTIONS FOR A NEW DEFINITION}

Up to this point, we presented the concepts of hybridity, hybridization and hybrid organization and discussed the limits of the latter concept. In this section, we will seek to broaden the understanding of the phenomenon of hybrid organizations and "speculate" about its causes, expressions and consequences.

\section{Causes of the hybridization process and the emergence of hybrid organizations}

Globalization-related changes are among the causes of the hybridization process and the emergence of hybrid organizations. Among such changes, we may highlight: first, the limits experienced by the State in providing services to the population, which gave rise to the emergence and proliferation of non-profit organizations (SALAMON, 1994); second, the liberalization of national markets, which increased competition, causing privatization processes (RAMAMURTI, 2000), industry consolidation processes (mergers and acquisitions) and organizational change processes, including radical changes (GREGORIOU \& RENNEBOOG, 2007; VASCONCELOS, CALDAS \& WOOD JR, 2004); and third, the growth of capital markets, together with companies going public, which often entailed major changes in governance and management models, particularly in family businesses (BHATTACHARYA \& RAVIKUMAR, 2001; EHRHARDT $\&$ NOWALK, 2003).

Such changes could be clearly seen in developing countries, which experienced a rapid transition to market economy (such as Eastern European countries) or a rapid market opening process (such as Latin American countries) (BAUMANN, 2002). It may be argued that all the processes mentioned (i.e. emergence of non-profit organizations, privatizations, mergers and acquisitions, organizational change or companies going public) may generate hybrids, although it cannot be affirmed that the cause-and-effect relationship is absolute.

\section{Expressions of the hybridity phenomenon}

The sources compiled and discussed in the section on the existing theory provide indications of expressions of the hybridity phenomenon in organizations. However, this base must be expanded to take into account certain major organizational change processes occurred in Brazil, such as, for example, the privatization of the electricity and telephone systems; efforts to modernize and professionalize major Brazilian private groups; and merger and acquisition processes.

Based on a review of this expanded base, we suggest that the hybridity phenomenon may be seen in four main dimensions: governance systems; special structure and segregation; processes and systems; and discourse, culture and identity. These dimensions will be reviewed one by one.

The first dimension is governance systems. The hybrid governance condition is observable in the examples mentioned by Lamb and Davidson (2004) and by Anheier and Schöer (2008), i.e. public universities that provide consulting services to private companies and research centers that conduct studies for pharmaceutical laboratories. The hybrid governance condition may also be observed in organizations that combine features of non-profit organizations with features of business companies.

The second dimension is structure and spatial segregation. Based on observation of numerous consulting projects and case studies, one may 
conclude that hybridity is also expressed in the coexistence of parts from different sources. In companies that resulted from privatization processes, for example, it is common to find areas coming directly from the public corporation that originated the new organization, while new areas have been created from the hiring of professionals in the market.

The third dimension is processes and systems. Also based on case observation, it may be argued that hybridity is expressed in the juxtaposition of processes and systems. One change process that often generates hybrids is the implementation of integrated enterprise management systems (Enterprise Resource Planning - ERPs). Such implementations usually involve the adoption by companies of standardized flows for their core work processes. However, because of time constraints, internal resistance or peculiarities of the companies, adaptation is not always perfect (WOOD JR. \& CALDAS, 2001). Therefore, the result of the implementation work is often the coexistence of the new system and its new processes with inherited procedures and systems, which are operated in parallel and sometimes generate different information and results.

The fourth dimension is of discourse, culture and identity. This fourth dimension is probably among the most researched in organizational studies. Works in this field deal with rhetoric disputes (HARDY \& PHILLIPS, 1999; MAGUIRE \& HARDY, 2006), multiple identities (FOREMAN \& WHETTEN, 2002; HOFESTEDE, 1980; PRATT \& FOREMAN, 2000) and cultural diversity (GIOIA, SCHULTZ \& CORLEY, 2000; HAMPDEN-TURNER \& TROMPENAARS, 1998). In short, in this fourth dimension we must also accept the possibility of coexistence of different corpora (of discourses, culture or identity) in the same organizational corpus.

\section{Consequences of the hybrid condition}

It is intuitive to realize a challenge for management in the hybrid situation. However, it is helpful to adopt a simplified conceptual model for a better understanding of the consequences. This model, represented by Figure 1, involves an ideal hypothetical situation in which two organizations with different features merge, giving rise to a supposedly hybrid organization. The vertical axis records the level of salience of Company 1. The horizontal axis represents the level of salience of Company 2. Salience refers to the dimensions listed above, i.e. governance system; special structure and segregation; processes and systems; and discourse, culture and identity.

\section{Friendly coexistence}

Cell (3) represents a situation in which both companies are low salience, i.e. none of them is able to offer strong or dominant features. In this situation, individual features may remain for some time, thus maintaining the hybrid condition until the balance is changed or new features are imposed by some initiative.

Figure 1 - Relational model for hybrid organizations

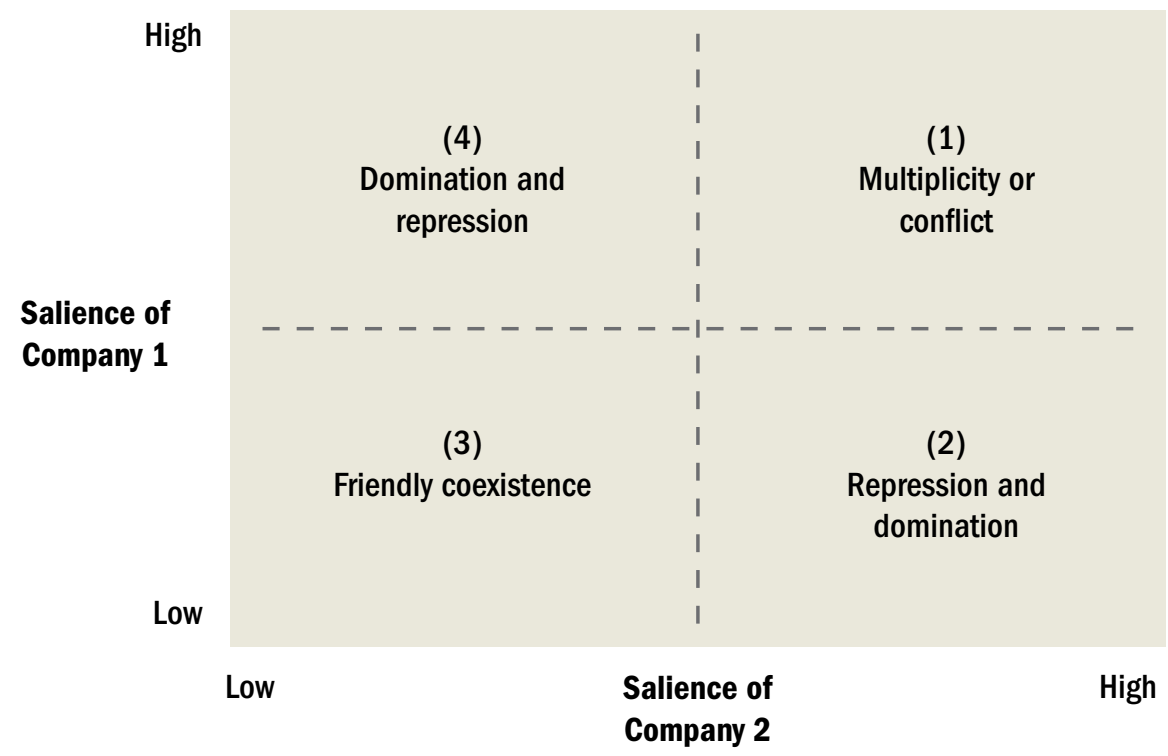


In situations similar to the one represented by cell (3), i.e. low salience, one may conclude that there is an accommodation from both parties if there is no external force for change. Thus, different models, systems and cultures may coexist for an indefinite period. This may imply barriers to generate economies of scale and scope, because systems and procedures will be duplicated, and additional coordination capacity will be required from top management coordination, particularly in agenda definition and decision-making processes.

\section{Domination and submission}

Cells (2) and (4) represent a different situation in which one of the companies presents a high level of salience compared to the other, which presents low salience. In both cases, one may assume that there will be a dynamics involving domination and submission, i.e. a company will seek to impose its features on the other.

In situations similar to the ones represented by cells (2) and (4), i.e. a combination of strong and weak salience, one may conclude that one organization (with strong salience) will tend to impose its features on the other (with low salience). This scenario is likely to be permeated by tensions and conflicts between the dominant perspective and the non-dominant perspective, with consequences such as deterioration of the organizational environment, emergence of resistance, increased organizational cynicism, higher incidence of organizational incivility cases and negative impacts on absenteeism, employee turnover productivity.

\section{Multiplicity or conflict}

Cell (1) represents the hybrid situation par excellence, or the scenario in which the hybrid condition may continue for the longest time. In this scenario, both organizations present high-salience features.

In situations similar to the one represented by the cell (1), i.e. strong salience, one may conclude that there may be situations of confrontation, with varying degrees of conflict, and each organization will seek to establish its features as dominant or at least to defend its territory. We argue that this scenario combines the challenges from the previous two scenarios, because it involves both the trend towards continuance of the features associated with the present organizations and permanent domination attempts by one or the other party.

\section{CONCLUSION}

In this paper, we sought to expand the perception of the concept of hybrid organizations. To achieve this goal, we summarized and reviewed the existing literature and sought to outline the phenomenon. In this last section, we will discuss additional issues. We will also review the contributions of the paper, identify its limitations and provide directions for future research.

\section{Additional Issues}

As mentioned above, this paper focused on the causes, expressions and consequences of the phenomenon of hybrid organizations. On the other hand, two relevant issues must be mentioned which, due to choice of scope, have not been addressed: first, are not all organizations potentially hybrid after all, reaching such status at least for a certain period of their existence? And second, what conditions would lead organizations to lose or soften their hybrid nature?

Regarding the first question, the initial answer is yes, at least for organizations that reach a certain degree of complexity. After all, every organization that restructures itself, expands regionally or internationally or acquires or is acquired by another becomes hybrid to some degree. But we should also consider that what makes hybridity a relevant phenomenon is not its mere existence, but the fact that it occurs in such a degree that generates significant interference or impact on management. Therefore, it may be suggested that all complex organizations are hybrid, but not all experience such a feature in a relevant degree.

Regarding the second question, it must admitted that the answer would require additional research and may even be the subject of an empirical study. However, some preliminary observations can be made. Just as the Negro River eventually mixes with the Solimões River, organizations may also lose or reduce their hybrid nature over time. This process may occur, for example, due to continued managerial action to promote greater uniformity in systems, structures or even attitudes and behaviors. Significantly, contemporary managerial rhetoric is populated by terms such as "strong culture," "corporate DNA" and "strong identity." The popularity of these terms indicates a systematic search for homogeneity (and therefore for a force contrary to hybridization). Therefore, it may be suggested that conscious managerial action, through the use of rhetoric and the usual management and control tools (e.g. hiring, firing, punishment and reward) is a driver to reduce the degree of hybridity.

\section{Contributions to theory and practice}

As stated in the introduction, this paper presents some contributions to organizational studies by drawing attention to a relevant, yet poorly studied, phenomenon, reviews and expands 
the concept of hybrid organizations and reveals the dynamics underlying this phenomenon.

For researchers, particularly those interested in organizational change processes, the adoption of the expanded hybrid organization concept may open new avenues of study. Such avenues may include, among others, the following possibilities: first, a comparative study of governance systems that may accommodate the hybrid condition of certain organizations; second, a study of the conditions and effects of the coexistence between groups from different origins within an organization; third, a study of the impact of hybridization relating to the existence of processes and systems from different origins within the same organizational environment, such as the effects on the organization of work and on decision-making processes; and fourth, the study of the dimension of discourse, culture and identity in hybrid environments.

As for executives, the concept may be usefully applied to merger and acquisition processes, privatization and organizational changes. The recognition of the hybrid condition and hybrid organizations poses additional challenges to the conduct of large-scale intervention processes. First, one must emphasize knowledge of the history of the organization or organizations involved. It is important to identify their origin, major developmental milestones and critical events. This knowledge allows us to understand the dynamics underlying the formation of hybrids. Second, one must identify the groups within the organization, as well as their respective physical spaces. The purpose of this mapping is to understand motives and actions, which allows us to determine the best intervention strategy. Third, one must identify expressions of hybridity, both in relation to objective features (e.g. models, processes, systems and procedures) and subjective features (e.g. organizational culture, organizational identity and discourses). Such identification must be accompanied by a review of the respective levels of salience. Fourth, it is advisable to identify the main points of tension and conflict generated by the presence of hybrids. Both must be considered. Fifth, one must establish the intervention strategy. Such strategy must consider the results of previous steps and a review of the level of salience of the features.

\section{Limitations e future research}

The essay nature of this paper implies two limitations that may lead to further research. The first limitation refers to the model being proposed (Figure 1), which, although it serves the didactic purposes of this paper, presents a static and bipolar picture of the phenomenon (with only two organizations). The hybridization process is dynamic and intricate and could easily escape the eye of an observer. Therefore, future research should seek to capture such dynamics.

The second limitation concerns the empirical base. Future research should involve case studies. A grounded theory model (Eisenhardt, 1989) may be used for this purpose in order to identify broader patterns and expand the understanding of the phenomenon. Finally, we expect, as usual, that this paper will be regarded as an invitation to future developments related to the subject of hybrid organizations.

\section{ACKNOWLEDGEMENTS}

This work benefited from Ruth Steuer's studies on hybridity in culture, from the development of the concept of inherited identity and its dynamics, originally designed by Michael P. Caldas, and from comments by anonymous reviewers.

\section{REFERENCES}

AGUILERA, R. V; CUERZO-CAZURRA, A Codes of good governance worldwide: what is the trigger? Organization Studies, v. 25, n. 3, p. 415-443, 2004

ANHEIER, H. K; SCHRÖER, A. The governance of hybrid organization: The case of social entrepreneurship \& corporate social responsibility. Heidelberg: Heidelberg Universität, CSI - Centre for Social Investment, 2008.

BAUMANN, R. Brazil in the 1990s: an economy in transition. Basingstoke: Palgrave Macmillan, 2002

BHABHA, H. K. O local da cultura. Belo Horizonte: Editora UFMG, 2003.

BHATTACHARYA, U; RAVIKUMAR, B. Capital markets and the evolution of family businesses Journal of Business, v. 74, n. 2, p. 187-220, 2001

BURKE, P. Hibridismo cultural. São Leopoldo: Editora Unisinos, 2003.

CALÁS, M. B; ARIAS, M. E. Compreendendo as organizações latino-americanas: transformação ou hibridização? In: MOTTA, F. C. P; CALDAS, M. P. (Eds) Cultura organizacional e cultura brasileira. São Paulo: Atlas, 1997

CHAN, K-B; LUK, V; WANG, G. X. Conflict and innovation in international join-ventures: toward a new signified corporate culture or "alternative globalization" in China. Asia Pacific Business Review, v. 11, p. 461-482, 2005.

EHRHARDT, O; NOWALK, E. The effect of IPOs on German family-owned firms: governance, changes, ownership structure, and performance. Journal of Small Business Management, v. 41, n. 2, p. 222-232, 2003.

EISENHARDT, K. Building theory from case study research. Academy of Management Review, v. 14, n. 4, p. 532-550, 1989.

FOREMAN, P; WHETTEN, D. Members' identification with multiple-identity organizations Organization Science, v. 13, n. 6, p. 618-635, 2002

FRANKEL, M; SHENHAV, Y. From americanization to colonization: the diffusion of productivity models revisited. Organization Studies, v. 24, n. 9, p. 1537-1561, 2003. 
GARCIA-CANCLINI, N. Noticias recientes sobre la hibridación. Revista Transcultural de Música, v. 7. Available at http://www.sibetrans.com/ trans/trans7/canclini.htm, 2003a. Retrieved on 02.28.2006.

GARCIA-CANCLINI, N. Culturas híbridas: estratégias para entrar e sair da modernidade. São Paulo: Editora da Universidade de São Paulo, 2003b.

GIOIA, D; SCHUlTZ, M. CORlEy, K. Organizational identity, image, and adaptive instability. Academy of Management Review, v. 25, n. 1, p. 63-81, 2000.

GREGORIOU, G; RENNEBOOG, L. International mergers and acquisitions activity since 1990. Academic Press, 2007.

HAMPDEN-TURNER, C; TROMPENAARS, F. Riding the waves of culture: understanding diversity in global business. New York: McGrawHill, 1998.

HARAWAY, D. J. Manifesto ciborgue: ciência, tecnologia e feminismo socialista no final do século XX. In: SILVA, T. T. (Org) Antropologia do ciborgue: as vertigens do pós-humano. Cap. 3, p. 37-129. Belo Horizonte: Autêntica, 2000.

HARDY, C; PHILLIPS, N. No joking matter: discursive struggle in the Canadian refugee system. Organization Studies, v. 20, n. 1, p. 1-24, 1999.

HATCH, M. J. Organization theory: modern, symbolic and postmodern perspectives. New York: Oxford University Press, 2007.

HOFSTEDE, G. Culture's consequences: international differences in work-related values. Beverly Hills: Sage, 1980.

HUDNUT, P; BAUER, T; LORENZ, N. Appropriate organizational design: a hybrid business model for technology transfer to the developing world. 10th ANNUAL MEETING OF THE NATIONAL COLLEGIATE INVENTORS AND INNOVATORS ALLIANCE. Available at http://www.nciia.org/ conf_06/papers/pdf/hudnut.pdf, 2006. Retrieved on 09.24.2008.

KANTER, R. M; STEIN, B. A; JICK, T. D. The challenge of organizational change. New York: The Free Press, 1992.

KOPPELL, J. The politics of quasi-government. Cambridge: Cambridge University Press, 2003.
LAMB, R; DAVIDSON, E. Hybrid organization in high-tech enterprise. 17th BLED ECOMMERCE CONFERENCE EGLOBAL. Bled, Slovenia, 2004.

LAMMERS, C. J. Transient and persistence of ideal types in organization theory. Research in the Sociology of Organizations, v. 6, p. 203-224, 1988.

LANE, C. Changes in corporate governance of German corporations: convergence to the AngloAmerican model. Competition \& Change, v. 7, $\mathrm{n}$. 2/3, p. 79-100, 2003.

MAGUIRE, S; HARDY, C. The emergence of new global institutions: a discursive perspective. Organization Studies, v. 27, n. 1, p. 7-29, 2006.

MARKS, M. L; MIRVIS, P. H. Joining forces: making one plus one equal three in merger, acquisitions, and alliances. San Francisco: Jossey-Bass, 1998.

MÉNARD, C. The economics of hybrid organizations. Journal of Institutional and Theoretical Economics, v. 160, p. 345-376, 2004.

MINTZBERG, H. Mintzberg on management: Inside our strange world of organizations. New York: The Free Press, 1989.

PRATT, M; FOREMAN, P. Classifying managerial responses to multiple organizational identities. Academy of Management Review, v. 25, n. 1, p. $18-42,2000$.

PREFEITURA DE MANAUS. Encontro das águas. Available at http://www.manaus.am.gov.br/turismo/atrativos-naturais/encontro-das-aguas/, 2007. Retrieved on 23.12.2008.

PUdELKO, M; MENDENHALl, M. E. The Japanese management metamorphosis: what western executives need to know about current Japanese management practices. Organizational Dynamics, v. 36, n. 3, p. 274-287, 2007.

RAMAMURTI, R. A multilevel model of privatization in emerging economies. Academy of Management Review, v. 25, n. 3, p. 525-550, 2000.

SALAMON, L. M. The rise of the nonprofit sector. Foreign Affairs, v. 73, p. 109-122, 1994.

SHIMONI, B. Separation, emulation and competition: hybridization styles of management cultures in Thailand, Mexico and Israel. Journal of Organizational Change, v. 21, n. 1, p. 107119,2008
SHIMONI, B; BERGMANN, H. Managing in a changing world: from multiculturalism to hybridization - the production of hybrid management cultures in Israel, Thailand, and Mexico. Academy of Management Perspectives, v. 20, n. 3 , p. 76-89, 2006.

THE ECONOMIST. After the deal, January 9, p 21-23, 1999a.

THE ECONOMIST. How to make mergers work, January 9, p. 15-16, 1999b.

THE ECONOMIST. Twin twisters, July 17, p. 15,2008

VASCONCELOS, F. C; CALDAS, M. P; WOOD JR, T. Ambev: the making of a Brazilian giant. In: MINTZBERG, H; GHOSHAL, S; LAMPEL, J; QUINN, J. B. (Orgs) The Strategy Process. 4. ed. p. 229-233. Upper Saddle River: Prentice Hall, 2003.

VASCONCELOS, F. C; CALDAS, M. P; WOOD JR, T. Fusões e aquisições no Brasil: uma análise crítica do teatro de operações, Revista Comportamento Organizacional e Gestão, v. 10, n. 1, p. $43-58,2004$

WALLACE, T. Innovation and hybridization: managing the introduction of lean production into Volvo in Brazil. International Journal of Operations \& Production Management, v. 24, n. 8, p. 801-819, 2004.

WHITFORD, J; ZEITLIN, J. Governing decentralized production: institutions, public policy, and the prospects for inter-firm collaboration in US manufacturing. Industry and Innovation, $\mathrm{v} .11, \mathrm{n}$. 1/2, p. 11-44, 2004.

WILLIAMSON, O. E. The economic institutions of capitalism. New York: Free Press, 1985.

WILLIAMSON, O. E. Comparative economic organization: the analysis of discrete structural alternatives. Administrative Science Quarterly, v. 36, p. 269-296, 1991

WILSON, D. A strategy of change: concepts and controversies in the management of change. New York: Routledge, 1992

WOOD JR, T; CALDAS, M. P. Reductionism and complex thinking during ERP implementations. Business Process Management Journal, v. 7, n. 5 , p. 387-393, 2001. 